\title{
The composition of the arthropod fauna of the canopies of some species of oak (Quercus)
}

\author{
T. Richard E. SOUTHWOOD, G.R. William WINT, Catherine E.J. KENNEDY* and Steve R. GREENWOOD** \\ Department of Zoology, South Parks Road, Oxford OX1 3PS, UK; e-mail: richard.southwood@zoo.ox.ac.uk
}

Key words. Canopy fauna, guilds, Quercus, species richness, introduced species, tourist guild, prey/predator ratio, epiphyte grazers

\begin{abstract}
A study was made by knockdown sampling and branch clipping of the arthropod fauna of the canopy of two native oak species (Quercus robur and Q. petraea) and of two introduced species (Q. cerris and Q. ilex) in woods near Oxford, UK, and of two native species (Q. pubescens and $Q$. ilex) in southern France. Sampling was undertaken for five years in the UK and for four years in France. All the specimens from the UK, except Acarina, Collembola and Nematocera were identified to species or, occasionally, to morphotype.

2. In terms of overall numbers, species richness and biomass, the results for Q. robur and Q. petraea in the UK were very similar. Their samples contained over three times the biomass and nearly double the number of species compared with those from the introduced oak species (Q. cerris and Q. ilex).

3. The ordinal composition was very similar on $Q$. robur and Q. petraea, and that on $Q$. cerris showed closer concordance to the composition of these trees than to that of $Q$. ilex in the UK. The ordinal composition of the faunas of the two native oak species in France showed closer concordance to each other than to any of the oak species in the UK. The proportion of Psocoptera was much higher in the UK, and that of Thysanoptera was higher in France.

4. The guild composition in terms of numbers, species richness and biomass were closely correlated on Q. robur and Q. petraea, and on $Q$. robur in two different woods, which argues for an underlying determinism in the development of community structure. The guild composition on the introduced species ( $Q$. cerris and $Q$. ilex) was most closely correlated when expressed as species richness.

5. The similarity of the guild composition on the oak species in the UK in terms of the actual species found was tested by a modified Sørensen's Index. This showed that the guilds could be ranked in the following order of decreasing similarity: epiphyte fauna, tourists, scavengers, phytophages, parasitoids-predators.

6. There were distinct seasonal patterns. In terms of species richness the values showed a general trend peaking in summer and early autumn, but biomass peaked in May on the native oak species, mainly due to Lepidopterous larvae. The ratio of prey to predator and parasitoid biomass had a distinct seasonal pattern, there being an excess of prey in May, but almost an equivalence throughout the rest of the season. This may reflect the high population of spiders in the late summer and autumn, which are likely to feed on tourists. Most classical ecosystem models do not allow for this latter important source of food that is not itself dependent on the communities' habitat.

7. The epiphyte dwelling guild (principally grazing Psocoptera) was a major component of the fauna in terms of numbers on the evergreen $Q$. ilex in UK. This has been reported for other studies of evergreen species in temperate climates.
\end{abstract}

\section{INTRODUCTION}

The present paper reports the findings of a study carried out in Southern Britain and Southern France of the total arthropod fauna of the canopy of various species of oak (Quercus). A detailed account of the phytophage guild is given in Southwood et al. (2004).

Methods of sampling the arthropod fauna of tree canopies are relatively well developed (Mitchell et al., 2002) and they thus provide tractable systems for the study of community composition and function (e.g. Stork et al., 1997; Linsenmair et al., 2001; Basset et al., 2003 ). Most of these studies have been made in tropical or subtropical forests, relatively few in temperate regions (e.g. Moran \& Southwood, 1982; Fowler, 1985; LeCorff \& Marquis, 1999).

On the basis of a comparative study of the canopy fauna of various trees in the UK and South Africa, Moran
\& Southwood (1982) suggested that certain generalisations could be made about the proportional sizes of various major guilds. West (1986) and Stork (1987a) made similar observations. These studies were based on samples taken from only a few trees on a single occasion. Intertree and seasonal variation has been widely recognised (Erwin \& Scott, 1980; Basset, 1991), and Mody et al. (2003) rejected the hypothesis that assemblies on conspecific trees are the same. The question remains as to whether the averages show consistent patterns if sufficient samples are taken over time and space. The present study, based on five years of sampling, seeks to determine whether meaningful patterns emerge from the accumulated data.

\footnotetext{
* Present address: Oxord University Press, Great Clarendon Street, Oxford OX2 6DP, U.K.

** Present address: BBC Natural History Unit, Whiteladies Road, Bristol BS8 2LR, U.K.
} 
APPENDIX 1. Persons who undertook the identifications.

\begin{tabular}{lll}
\hline Araneae & & M. Amphlett \\
Coleoptera & Cantharidae & K. Alexander \\
& Staphylinoidea & D. Mann \\
& Others & G.C. McGavin, \\
& & T.R.E. Southwood, \\
& M. Robinson \\
Diptera & Muscidoidea & A. Pont \\
& Others & J. Ismay, \\
Heteroptera & & S.R. Greenwood \\
& & T.R.E. Southwood, \\
"Homoptera" & Auchenorrhyncha & G.C. McGavin \\
& Sternorrhyncha & J. Kathrithamby \\
Hymenoptera & Aculeata & C.J. Kennedy \\
& Chalcidoidea & R.R. Askew \\
& Cynipoidea & C.J. O’Toole \\
& Symphyta & C.J. O’Toole \\
Lepidoptera & Others (morphotyped) & L.C. Cole \\
Psocoptera & & G.R.W. Wint \\
Others & & S.R. Greenwood \\
& & S.R. Greenwood, \\
& & T.R.E. Southwood \\
\hline
\end{tabular}

\section{METHODS}

The canopy fauna of four species of oak in the UK, two native ( $Q$. petraea and $Q$. robur) and two introduced (Quercus cerris and $Q$. ilex), were sampled by pyrethroid knockdown and branch clipping from 1980 to 1984 in Wytham Wood $\left(57^{\circ} 46^{\prime} \mathrm{N}, 1^{\circ} 19^{\prime} \mathrm{W}\right)$ and Bagley Wood $\left(57^{\circ} 43^{\prime} \mathrm{N}, 1^{\circ} 15^{\prime} \mathrm{W}\right)$ near Oxford. A total of 183 samples were taken between April and October, which yielded some 61,000 arthropods. All except Nematocera, Aracina and Collembola have been identified to species or morphotype. Similar methods were used from 1982 to 1984 between May and August in Southern France to sample the canopy fauna of two native species of oak $(Q$. ilex and $Q$. pubescens) in the hamlet of 1'Elzieres, Mars, Gard $\left(44^{\circ} 0^{\prime} \mathrm{N}\right.$, $3^{\circ} 33^{\prime} \mathrm{E}$ ), in the Cevennes. These 42 samples produced approximately 12,000 specimens, which were separated into orders, though as only the Heteroptera, Coleoptera and Psocoptera were identified to species, only a partial analysis was possible, and overall composition and guild composition were not assessed. Full details of the sampling methods are given in Southwood et al. (2004). The names of those responsible for identifications are given in Appendix 1.

Species were classified into major guilds largely following the allocations of Moran \& Southwood (1982), but members of the Staphylinidae that are fungivorous, and of the Fannidae whose larvae breed in rotten wood, were assigned to the scavenger guild, thereby addressing in part the concerns that Stork (1987a) correctly raises over guild allocation.

Data processing and analyses were carried out using Statistical Package for the Social Sciences (SPSS) and the Species Diversity and Richness Analysis software produced by Pisces Ltd to calculate a series of diversity measures (Chao quantitative, First Order Jacknife, and Michaelis-Menton estimators of maximum species number), as well as the Sørensen Index of Similarity (see below). Further details and rationale are provided in Southwood et al. (2004).

\section{RESULTS}

\section{Overall composition}

The mean numbers of individuals and species and the total biomass over all five seasons are given in Table 1. Although the fauna of $Q$. petraea was sampled only in Bagley Wood and that of $Q$. robur both there and at Wytham, there was a remarkably close similarity in the values of the sample means for these two species. They showed over three times the biomass and nearly twice the number of arthropod species found on $Q$. cerris and $Q$. ilex. However the number of individuals on the latter species was similar to that on $Q$. petraea and $Q$. robur, showing that it was inhabited by some abundant but small species, notably epiphyte grazing Psocoptera, in particular Graphopsocus cruciatus (especially in June and August) and Cerobasis guestfalica (especially in July and August).

\section{Ordinal composition}

The relative abundance of each order as a proportion of the total catch is given in Table 2. The extent of concordance between the canopy fauna of the different oak species can be assessed quantitatively from the raw data using Kendall's W (Table 3). Both Tables 2 and 3 show the close similarity in ordinal composition of the fauna on the native and deciduous oak species, $Q$. robur and $Q$. petraea, in the UK. The composition of the fauna on the introduced and deciduous $Q$. cerris showed closer concordance with the ordinal composition on these two native trees than with the introduced and evergreen $Q$. ilex. The faunas on the two native oak species in France were more similar to each other than to those of any of the oak species in the UK. This would suggest that the composition of the species pool is distinct in the two locations and that this difference outweighs any similarities between the fauna of $Q$. ilex in UK and S. France.

TABLE 1. The mean number of individuals per sample and the total numbers of species, of samples taken from the four oak species near Oxford. (Standard Errors in Brackets.)

\begin{tabular}{lcccc}
\hline & Q. petraea & Q. robur & Q. cerris & Q. ilex \\
\hline Mean / Sample & & & & \\
$\quad$ Number individuals & $334(50.3)$ & $375(25.6)$ & $233(40.9)$ & $352(69.4)$ \\
Biomass (mg) & $889(137.2)$ & $825(90)$ & $236(39.8)$ & $243(51.9)$ \\
$\quad$ Species & $68(10.5)$ & $70(7.6)$ & $41(7.0)$ & $43(9.2)$ \\
Totals & & & 8170 & 7743 \\
$\quad$ Number individuals & 14023 & 31491 & 543 & 431 \\
Species (excluding Nematocera) & 801 & 1149 & & \\
\hline
\end{tabular}


TABLE 2. Proportion of each order in samples from five oak species taken between May and August, based on ordinal counts. Does NOT include percentage contribution to total numbers by Collembola (about $0.6 \%$ from total 504 indviduals) and Acarina (around 1.8\% from 1549 individuals).

\begin{tabular}{|c|c|c|c|c|c|c|}
\hline $\begin{array}{l}\text { Site } \\
\text { Quercus } \\
\text { TAXON }\end{array}$ & $\begin{array}{c}\text { UK } \\
\text { petraea }\end{array}$ & $\begin{array}{l}\mathrm{UK} \\
\text { robur }\end{array}$ & $\begin{array}{c}\text { UK } \\
\text { cerris }\end{array}$ & $\begin{array}{l}\text { UK } \\
\text { ilex }\end{array}$ & $\begin{array}{c}\text { France } \\
\text { ilex }\end{array}$ & $\begin{array}{c}\text { France } \\
\text { pubescens }\end{array}$ \\
\hline Araneae & 3.4 & 2.6 & 2.4 & 2.4 & 1.5 & 2.3 \\
\hline Coleoptera & 6.9 & 6.3 & 8.6 & 4.5 & 4.3 & 12.0 \\
\hline Dermaptera & 0.1 & 0.0 & 0.1 & 0.0 & 0.0 & 0.0 \\
\hline Diplopoda & 0.0 & 0.0 & 0.0 & 0.0 & 0.0 & 0.0 \\
\hline Diptera & 12.0 & 10.0 & 11.7 & 19.8 & 6.5 & 13.3 \\
\hline Ephemeroptera & 0.0 & 0.0 & 0.0 & 0.0 & 0.0 & 0.0 \\
\hline Heteroptera & 6.7 & 6.9 & 8.1 & 3.2 & 1.3 & 17.4 \\
\hline "Homoptera" & 7.8 & 5.9 & 4.2 & 8.9 & 4.3 & 4.6 \\
\hline Hymenoptera Parasitica & 14.9 & 12.9 & 6.9 & 1.8 & 8.3 & 14.5 \\
\hline Hymenoptera Symphyta/Aculeata & 0.3 & 0.2 & 0.1 & 0.0 & 0.1 & 0.1 \\
\hline Isopoda & 0.1 & 0.0 & 0.0 & 0.1 & 0.0 & 0.0 \\
\hline Lepidoptera & 11.5 & 11.2 & 3.4 & 0.7 & 0.8 & 9.5 \\
\hline Mecoptera & 0.0 & 0.0 & 0.0 & 0.0 & 0.0 & 0.0 \\
\hline Neuroptera & 0.3 & 0.5 & 0.7 & 0.4 & 1.6 & 1.4 \\
\hline Opiliones & 0.3 & 0.6 & 0.3 & 0.5 & 0.0 & 0.0 \\
\hline Orthoptera & 0.5 & 0.3 & 0.1 & 0.0 & 0.1 & 0.4 \\
\hline Plecoptera & 0.0 & 0.0 & 0.0 & 0.0 & 0.1 & 0.0 \\
\hline Psocoptera & 34.5 & 41.2 & 46.5 & 54.2 & 1.9 & 1.8 \\
\hline Thysanoptera & 0.7 & 1.3 & 7.0 & 3.3 & 69.4 & 22.7 \\
\hline Trichoptera & 0.0 & 0.0 & 0.1 & 0.0 & 0.0 & 0.0 \\
\hline Total & 100.0 & 100.0 & 100.0 & 100.0 & 100.0 & 100.0 \\
\hline
\end{tabular}

In the UK the major distinction between the faunas on the native and introduced oak species was the low populations of Lepidoptera on the latter which would have the effect of enhancing the proportion constituted by the remaining groups. A further striking feature is the difference in the proportion of the Psocoptera and Thysanoptera in the faunas of trees in the UK and France (Table 2).

\section{Guild composition}

The means per sample for the different guilds in terms of individual numbers, species richness and biomass levels are given in Table 4; the similarity between the guild compositions on one oak and another, as tested by calculating the correlation coefficient, are given in Table 5 . These results show the close similarity in all measures between the arthropod fauna of $Q$. petraea and $Q$. robur,

TABLE 3. Kendall's W using raw numbers for proportions of orders.

\begin{tabular}{lccccc}
\hline & UK & UK & UK & UK & France \\
robur & petraea & cerris & ilex & ilex \\
\hline UK petraea & 0.98 & & & & \\
UK cerris & 0.97 & 0.96 & & & \\
UK ilex & 0.90 & 0.92 & 0.94 & & \\
France ilex & 0.87 & 0.90 & 0.91 & 0.89 & \\
France pubescens & 0.90 & 0.90 & 0.93 & 0.86 & 0.94 \\
\hline
\end{tabular}

while the guild compositions of the introduced oak species were most similar to those of the native oak species when expressed in terms of species richness. It is in terms of biomass that the fauna of the evergreen $Q$. ilex differed most from that of the other oak species. The guild composition on $Q$. robur in Wytham was closely correlated with that found in Bagley: $\mathrm{r}=0.87^{* *}$ for numbers, $0.98^{* * *}$ for species richness and $0.99 * * *$ for biomass level.

The species composition of the guilds on the different trees can be compared using the Sørensen Index in a manner analogous to the way that it was used by Moran $\&$ Southwood (1982). The Index is:

$$
\mathrm{C}_{\mathrm{s}}=2 \mathrm{jS} /(\mathrm{aS}+\mathrm{bS}) \times 100
$$

where $\mathrm{C}_{\mathrm{s}}$ is the percentage similarity, jS is the number of species common to the fauna of the two oak species being considered, and aS and bS are the total species on tree species "a" and tree species "b" respectively. It should be noted that this approach takes no account of the relative abundance of the species. The results can be clearly expressed in dendrograms (Fig. 1). From these it can be seen that the guilds can be ranked in terms of decreasing overall similarity as follows: epiphyte fauna, scavengers, tourists, phytophages and predators/parasitoids. In the two latter guilds, whose species are most specific to particular species of oak or their fauna, the similarity is greatest between those on $Q$. robur and those on $Q$. petraea, while those on $Q$. ilex in the UK are most dis- 
TABLE 4. Annual means per sample for the different guilds on the four oak species near Oxford.

\begin{tabular}{lcccc}
\hline & petraea & robur & cerris & ilex \\
\hline Number & & & & \\
$\quad$ Phytophages & 100.1 & 94.9 & 37.2 & 43.3 \\
Predators & 39.4 & 35.2 & 19.9 & 27.3 \\
Parasitoids & 43.5 & 43.0 & 15.0 & 7.6 \\
Scavengers & 10.0 & 12.2 & 8.7 & 12.3 \\
Epiphyte Fauna & 109.1 & 153.1 & 132.5 & 200.6 \\
Tourists & 15.6 & 9.9 & 6.4 & 15.4 \\
Species & & & & \\
Phytophages & 19.1 & 21.2 & 10.7 & 6.5 \\
Predators & 13.3 & 13.7 & 10.9 & 12.4 \\
Parasitoids & 20.2 & 18.8 & 7.3 & 5.3 \\
Scavengers & 3.9 & 4.1 & 3.0 & 5.3 \\
Epiphyte Fauna & 5.1 & 5.9 & 4.9 & 6.3 \\
Tourists (excl Nematocera) & 5.5 & 5.4 & 3.7 & 6.4 \\
Biomass & & & & \\
Phytophages & 644.6 & 584.5 & 128.3 & 53.3 \\
Predators & 118.5 & 100.2 & 41.9 & 44.4 \\
Parasitoids & 31.8 & 32.9 & 6.4 & 5.8 \\
Scavengers & 20.9 & 16.1 & 5.3 & 12.7 \\
Epiphyte Fauna & 42.6 & 59.4 & 37.5 & 86.0 \\
Tourists & 21.7 & 17.0 & 9.2 & 16.5 \\
\hline
\end{tabular}

similar. As might be expected, the scavenging and tourist guilds exhibited a greater similarity on all the oak species. The epiphyte fauna which, like the tourists, has no direct trophic link to the trees themselves, showed the greatest similarity on all the trees.

The epiphyte fauna is composed almost entirely of Psocoptera which, as can be seen from Table 2, were numerically well represented on the trees in the UK, but poorly represented in the drier habitat in France. Estimates can be made of the total species richness $\left(\mathrm{S}_{\max }\right)$ present on the different trees (Table 6). The three estimators (Southwood \& Henderson, 2000) give broadly comparable results. In the UK the community on $Q$. cerris is the least
TABLE 5. The correlation coefficient $\left(\mathrm{r}^{2}\right)$ for the guild composition given in Table 4

\begin{tabular}{|c|c|c|c|}
\hline & petraea & robur & cerris \\
\hline \multicolumn{4}{|l|}{ Number } \\
\hline robur & $0.901 * *$ & & \\
\hline cerris & 0.560 & $0.840^{* *}$ & \\
\hline ilex & 0.442 & 0.750 & $0.986 * * *$ \\
\hline \multicolumn{4}{|l|}{ Species } \\
\hline robur & $0.992 * * *$ & & \\
\hline cerris & $0.992 * * *$ & $0.985 * * *$ & \\
\hline ilex & $0.830^{* *}$ & 0.732 & $0.816^{* *}$ \\
\hline \multicolumn{4}{|l|}{ Biomass } \\
\hline robur & $0.998 * * *$ & & \\
\hline cerris & $0.946 * * *$ & $0.959 * * *$ & \\
\hline ilex & 0.057 & 0.076 & 0.204 \\
\hline
\end{tabular}

species rich. Although psocids can spend the whole year on the evergreen $Q$. ilex in the $\mathrm{UK}$, this community, though more abundant, was not more species rich than those on the deciduous native species, which are maintained by an annual migration (Greenwood, 1988). In France, the epiphyte community on $Q$. pubescens was moderately species rich, although not numerous, while that on $Q$. ilex was poor. One can speculate that the more humid atmosphere associated with the deciduous leaves of the former species would encourage a more extensive epiphyte flora than the leathery leaves of the evergreen.

\section{Seasonal changes}

The mean values for each month in terms of individual numbers, species richness and biomass levels are shown in Fig. 2, which demonstrates that the number of both individuals and species exhibited the same general trend, peaking in summer and early autumn. However the pattern of biomass levels on the two native oak species in the UK was entirely different, with a sharp peak in early spring due mainly to lepidopterous caterpillars (Southwood et al., 2004).

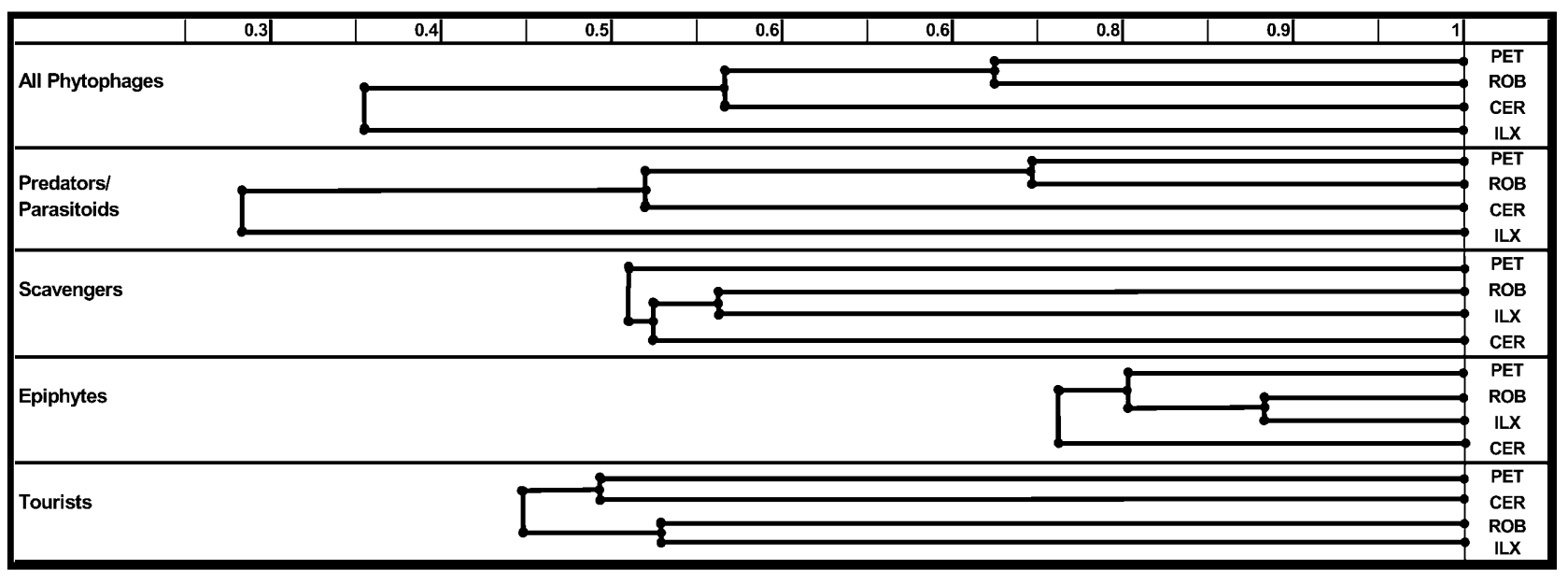

Fig 1. Sørensen dendrograms to show similarity in species composition of the different guilds on the four species of oak. 
TABle 6. The estimated species richness $\left(\mathrm{S}_{\max }\right)$ for the Psocoptera calculated by three methods.

\begin{tabular}{lcccccc}
\hline Site & UK & UK & UK & UK & France & France \\
Oak species & petraea & robur cerris & ilex & ilex & pubescens \\
\hline $\begin{array}{l}\text { Sample Number } \\
\text { Observed Psocid }\end{array}$ & 33 & 69 & 28 & 15 & 12 & 13 \\
$\begin{array}{l}\text { Species Number } \\
\text { Chao Quantitative }\end{array}$ & 18 & 24 & 16 & 20 & 5 & 7 \\
$\mathrm{~S}_{\max }$ & 18.9 & 24.4 & 16.3 & 20.7 & 5.4 & 15.0 \\
$\mathrm{SD}$ & 2.2 & 1.1 & 0.9 & 1.7 & 1.1 & 8.3 \\
$\mathrm{Michealis} \mathrm{Menton}_{\text {S }}$ & & & & & & \\
$\mathrm{S}_{\max }$ & 20.2 & 25.1 & 18.1 & 23.9 & 6.2 & 11.6 \\
Jacknife & & & & & & \\
$\mathrm{S}_{\max }$ & 20.8 & 26.9 & 18.0 & 23.7 & 6.0 & 10.3 \\
SD & 1.6 & 1.7 & 1.4 & 1.7 & 0.9 & 1.6 \\
\hline
\end{tabular}

The large numbers of individuals on the introduced trees in the UK in June, July and August were mostly due to the high population of psocids (Fig. 2).

The ratios of prey to predators and parasitoids are plotted in Fig. 3, the most striking feature of which is the excess of prey over invertebrate predators and parasitoids on the native trees in May. This is the season when insectivorous birds feed extensively in the trees (Perrins, 1991). What is perhaps more unexpected is that on all trees from late summer onwards the biomass levels of potential prey only slightly exceeded that of predators and parasitoids, which theoretically might be expected to lead to prey extinction. However, at this season many of the predators are spiders whose prey may be predominantly tourists, and these are being continually replaced from outside the community. This phenomenon is not allowed for in most traditional population models.

\section{DISCUSSION}

The mean number of individuals per square meter collecting tray ranged from 58 (Q. cerris) to 94 (Q. robur) (calculated from the $4 \mathrm{~m}^{2}$ knockdown sample, Table 1). Not surprisingly these values, based on the average over the whole season, were less than those for tropical areas: 137 to $476 / \mathrm{m}^{2}$ for plantation trees, $1628 / \mathrm{m}^{2}$ for secondary forest (Chey et al., 1998), and $1201 / \mathrm{m}^{2}$ for lowland rainforest (Stork \& Brendell, 1993). The mean biomass levels showed a greater range, from around $50 \mathrm{mg} / \mathrm{m}^{2}$ on the introduced species and over three times this amount on the native species. The seasonal trend of these means (Fig. 2) showed a peak of biomass in the late spring, but the numbers of individuals and of species remained approximately constant from May to September, though they were lower on the introduced species in May.

In the UK, the epiphyte grazing Psocoptera constituted between a third and half of the numbers of individuals sampled (Table 2), perhaps reflecting the relatively rich epiphyte flora supported by the host plant bark. Other studies have recorded similarly high proportions of various orders. For example, ants were found to be very abundant on a wide range of hosts, including savannah
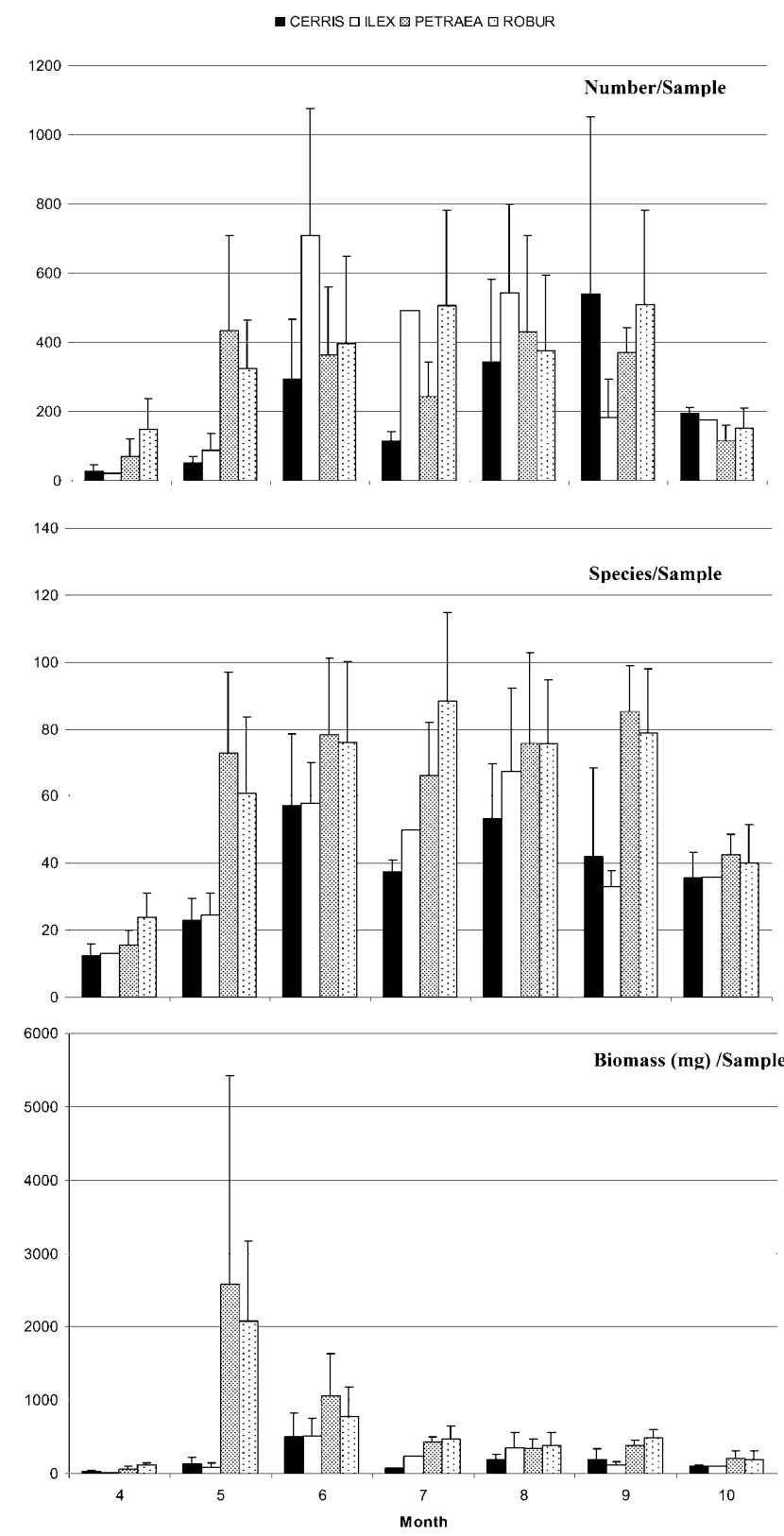

Fig 2. The seasonal pattern in terms of numbers, species richness and biomass on the four oak species in the U.K.

trees (West, 1986; Mody et al., 2003), certain Eucalyptus and Acacia (Majer et al., 2001); as well as in forest habitats in New Caledonia (Guilbert, 1997); and South-east Asian lowlands (Stork, 1987b, 1991; Stork \& Brendell, 1993). Other examples include Acari on Japanese Red Cedar, Cryptomeria, (Hijii, 1986); and in New Caledonian forests (Guilbert, 1997); and Collembola, also on Japanese Red Cedar (Hijii, 1986) and in New Caledonian forests (Guilbert, 1997), as well as in Queensland forests (Kitching et al., 1997) and Mexican tropical deciduous forest (Palacio-Varges et al., 1998). Each of these groups represented under $1 \%$ of our samples.

The canopy fauna of $Q$. robur and $Q$. petraea were very similar in species composition (Fig. 1) and in a number of other measures: mean numbers, species rich- 


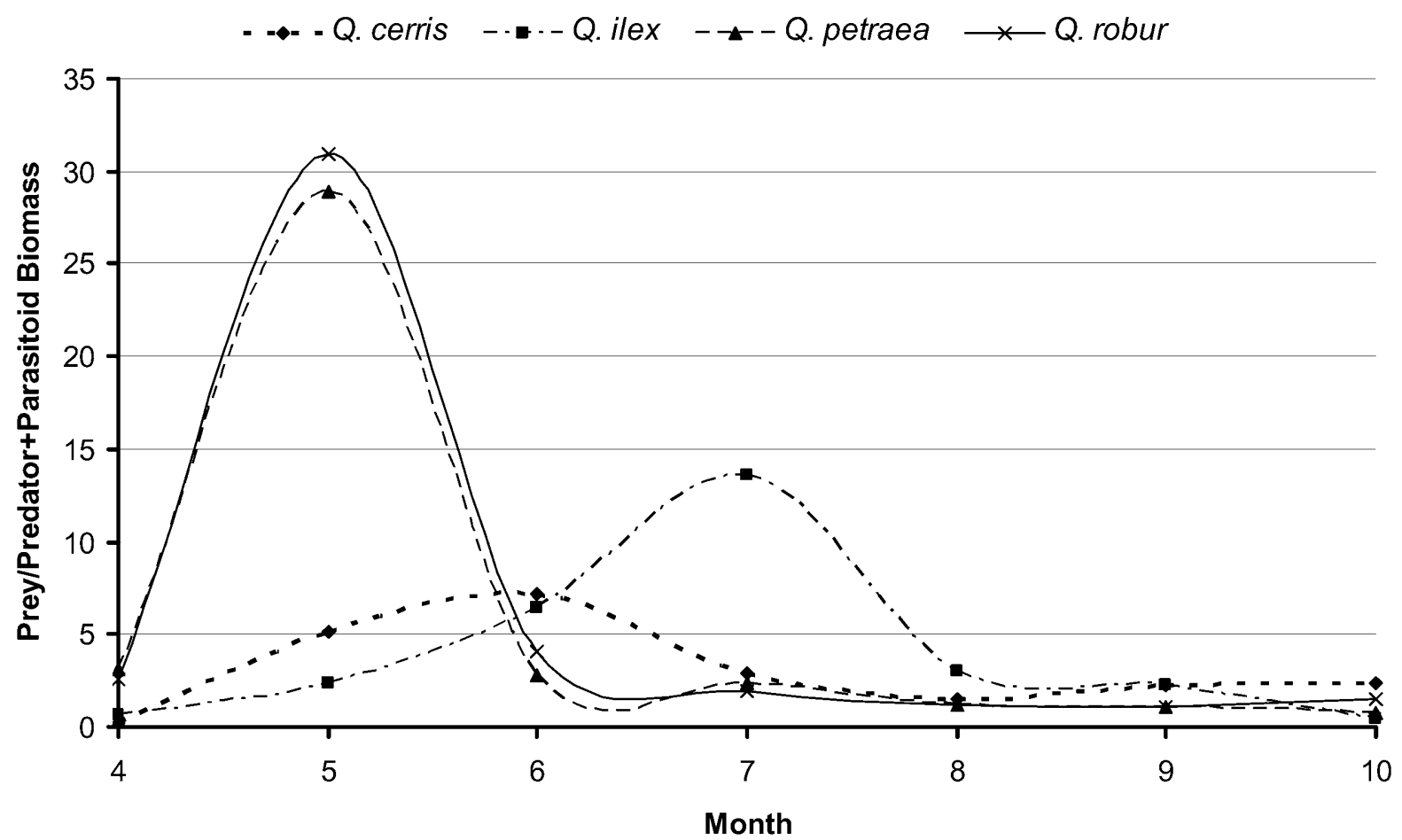

Fig 3. Prey/Predator + Parasitoid ratios (in terms of biomass) throughout the season.

ness and biomass (Table 1), ordinal composition (Table 3 ) and guild composition (Tables 4 and 5). The similarity between tree species and sites (Wytham and Bagley) argues for the concept of a deterministic pattern of community structure that is constrained within certain limits

TABLE 7. Proportion of numbers, species (excluding tourists), and biomass in each guild on the four species of oak in the UK as percentages.

\begin{tabular}{lcccc}
\hline & Q. petraea & Q. robur & Q. cerris & Q. ilex \\
\hline Numbers & & & & \\
$\quad$ Phytophages & 31.5 & 27.3 & 16.9 & 14.1 \\
Predators & 12.4 & 10.1 & 9.1 & 8.9 \\
Parasitoids & 13.7 & 12.4 & 6.8 & 2.5 \\
Scavengers & 3.2 & 3.5 & 4.0 & 4.0 \\
Epiphyte fauna & 34.3 & 43.9 & 60.3 & 65.5 \\
Tourists & 4.9 & 2.8 & 2.9 & 5.0 \\
Species & & & & \\
Phytophages & 30.9 & 33.3 & 29.1 & 18.2 \\
Predators & 21.6 & 21.6 & 29.6 & 34.6 \\
Parasitoids & 32.8 & 29.4 & 19.9 & 14.8 \\
Scavengers & 6.4 & 6.5 & 8.1 & 14.8 \\
Epiphyte fauna & 8.3 & 9.2 & 13.2 & 17.7 \\
Biomass & & & & \\
Phytophages & 73.2 & 72.1 & 56.1 & 24.3 \\
Predators & 13.5 & 12.4 & 18.3 & 20.3 \\
Parasitoids & 3.6 & 4.1 & 2.8 & 2.7 \\
Scavengers & 2.4 & 2.0 & 2.3 & 5.8 \\
Epiphyte fauna & 4.8 & 7.3 & 16.4 & 39.3 \\
Tourists & 2.5 & 2.1 & 4.0 & 7.5 \\
\hline
\end{tabular}

by ecological processes (Chase \& Leibold, 2003, p. 127) and that, with large enough samples, certain characteristic patterns can be recognised.

The large extent to which insect species are common to congeneric trees (Fig. 1) parallels similar observations by Basset (1992), Kitching et al. (1994), Basset \& Novotny (1999), Janzen (2003) and Novotny et al. (2003) and suggests caution in respect of a key assumption of host plant specificity in Erwin's (1982) estimate of global insect species numbers.

As with the phytophage guild (Southwood et al., 2004) the predator and parasitoid guild has a much higher species richness and abundance on the native species in the UK than on the introduced trees ( $Q$. cerris and $Q$. ilex) (Tables 4 and 5), confirming at a congeneric level the general observation made by Southwood (1961), Connor et al. (1980) and others that introduced hosts tend to support fewer arthropod species.

The fauna associated with epiphytes (mostly grazing Psocoptera) were similar in species composition on all the oak species in the UK (Fig. 1), but more abundant on the evergreen $Q$. ilex which provides a habitat for the whole season (Greenwood, 1988). The effect of this abundance of the fauna associated with epiphytes distinguishes the guild pattern on $Q$. ilex from that on the other species of oak (Tables 4, 5 and 7).

Comparisons between the patterns of guild composition found in this study and in others are best made in terms of proportional make-up (Table 7). Moran \& Southwood (1982) noted "this consistent pattern of proportional uniformity for species number in the phytophagous and predatory guilds ... suggests ... about $23 \%$ phytophages 
and about $20 \%$ predators". A comparison can be made of the results from the current work with those of Moran \& Southwood (1982), recalculated to exclude the tourists not identified here. This gives inventory values for $Q$. robur of $29 \%, 22 \%$ (S. Africa) and 26\%, 23\% (UK). The comparable values for $Q$. robur in this study are $35 \%$ and $22 \%$ (Table 7).

The proportions of phytophagous and predatory species on $Q$. petraea are not dissimilar to those on $Q$. robur, but were very different on the evergreen $Q$. ilex (Table 7), where the epiphyte grazing guild constitutes a larger proportion. Hijii (1986) also found that the epiphyte grazers constituted a large proportion of the fauna on the evergreen Japanese Red Cedar, as did Hodge et al. (2001) on the evergreen Kawakawa (Macropiper excelsior). This seems to be a feature of the canopy fauna of evergreen trees in temperate climates. The similarity of the guild proportions on the deciduous species in temperate climates found in this study was in accord with the findings of Stork (1987a) for SE Asian tropical rainforest trees and West (1986) for trees of the African savannah. This suggests that similar types of tree (e.g. deciduous or evergreen) in similar climatic areas show similar patterns in the proportions of the phytophagous and predatory guilds.

ACKNOWLEDGEMENTS. Our thanks are due to all those listed in Appendix 1, who have identified material for us and to L. Atkinson, J. Killick and A. Whittaker, who at various stages assisted with the compilation of data, and to former students who helped with the fieldwork and ordinal sorting. We are grateful to the President and Fellows of St. John's College, Oxford, for permission to work in Bagley Wood and to F. Galtier, the then mayor of Mars, Gard, France for permission to work on the lands of the community and on his own property. P. Henderson (Pisces Ltd) kindly made available to us his programmes for calculating $\mathrm{S}_{\max }$ and Sorensen's Index. We are indebted to the Natural Environment Research Council for its support of the initial work and to the Leverhulme Trust for the award of an Emeritus Fellowship to one of us (TRES). We are also indebted to two anonymous referees for their insightful comments and suggestions.

\section{REFERENCES}

BASSET Y. 1991: The seasonality of arboreal arthropods foraging within an Australian rainforest tree. Ecol. Entomol. 16: 265-278.

BASSET Y. 1992: Host-specificity of arboreal and free-living insect herbivores in rain forests. Biol. J. Linn. Soc. 47: 115-133.

BASSET Y. \& Novotny V. 1999: Species richness of insect herbivore communities on Ficus in Papua New Guinea. Biol. J. Linn. Soc. 67: 477-499.

Basset Y., Novotny V., Miller S.E. \& Kitching R.L. 2003: Arthropods of Tropical Forests: A Spatio-Temporal Dynamics and Resource Use in the Canopy. Cambridge University Press, $474 \mathrm{pp}$.

Chase J.M. \& Leibold M.A. 2003: Ecological Niches. University of Chicago Press, 212 pp.

Chey V.K., Holloway J.D., Hambler C. \& Speight M.R. 1998: Canopy knockdown of arthropods in exotic plantations and natural forest in Sabah, north-east Borneo, using insecticidal mist-blowing. Bull. Entomol. Res. 88: 15-24.
Connor E.F., Faeth S.H., Simberloff D. \& Opler P.A. 1980: Taxonomic isolation and the accumulation of herbivorous insects: a comparison of introduced and native trees. Ecol. Entomol. 5: 205-211.

ERwIN T.L. 1982: Tropical forests: their richness in Coleoptera and other arthropod species. Coleopt. Bull. 36: 74-75.

ERwin T.L. \& ScotT J.C. 1980: Seasonal and size patterns, trophic structure, and richness of Coleoptera in tropical arboreal ecosystem: the fauna of the tree Luehea seemannii Triana and Planch, in the Canal Zone of Panama. Coleopt. Bull. 34: 305-322.

FOWLER S.V. 1985: Differences in insect species richness and faunal composition of birch seedlings, saplings and trees: the importance of plant architecture. Ecol. Entomol. 10: 159-169.

GreENwoOd S.R. 1988: Habitat stability and wing length in two species of arboreal Psocoptera. Oikos 52: 235-238.

GUILBERT E. 1997: Arthropod biodiversity in the canopy of New Caledonian forests. In Stork N.E., Adis J. \& Didham R.K. (eds): Canopy Arthropods. Chapman \& Hall, London, pp. 265-277.

HiJII N. 1986: Density, biomass and guild structure of arboreal arthropods as related to their inhabited tree size in a Cryptomeria Japonica Plantation. Ecol. Res. 1: 97-118.

Hodge S., Frampton C., Maris J., Keesing V. \& Vin K.C. 2001: The trophic structure of the arthropod assemblage on Kawakawa, a New Zealand understorey tree. Entomol. Mon. Mag. 137: 173-178.

JANZEN D.H. 2003: How polyphagous are Costa Rican dry forest saturniid caterpillars. In Basset Y., Novotny V., Miller S.E. \& Kitching R.L.:Arthropods of Tropical Forests: A SpatioTemporal Dynamics and Resource Use in the Canopy. Cambridge University Press, pp. 369-379.

Kitching R.L., Floater G. \& Mitchell H. 1994: The biodiversity of arthropods from Australian rainforest canopies: ecological questions and management challenges. In Yasuno M. \& Watanabe M.M. (eds): Biodiversity: Its Complexity and Role. Global Environmental Forum, Tokyo, pp. 119-137.

Kitching R.L., Mitchell H., Morse G. \& Thebaud C. 1997: Determinants of species richness in assemblages of canopy arthropods in rainforests. In Stork N.E., Adis J. \& Didham R.K. (eds): Canopy Arthropods. Chapman \& Hall, London, pp. 131-150.

Le Corff J. \& Marquis R.J. 1999: Differences between understorey and canopy in herbivore community composition and leaf quality for two oak species in Missouri. Ecol. Entomol. 24: $46-58$.

Linsenmair K.E., Davis A.J., Fiala B. \& Speight M.R. (eds) 2001: Tropical Forest Canopies: Ecology and Management (Proceedings of European Science Foundation Conference, Oxford University, 12-16 December 1998). Kluwer Academic Publishers, Dordrecht, 370 pp.

Majer J.D., Recher H.F., Graham R. \& Watson A. 2001: The potential of revegetation Programs to encourage invertebrates and insectivorous birds. School of Environmental Biology Bulletin No 20. Curtin University of Technology, Perth, Western Australia, 32 pp.

Mitchell A.W., Secoy K. \& Jackson T. (eds) 2002: The Global Canopy Handbook. Global Canopy Programme, Oxford, 248 pp.

Mody K., Bardorz H.A. \& Linsenmair K.E. 2003: Organisation of arthropod assemblages in individual African savanna trees. In Basset Y., Novotny V., Miller S.E. \& Kitching R.L.: Arthropods of Tropical Forests: A Spatio-Temporal Dynamics and Resource Use in the Canopy. Cambridge University Press, pp. 198-212. 
Moran V.C. \& Southwood T.R.E. 1982: The Guild composition of arthropod communities on trees. J. Anim. Ecol. 51: 289-306.

Novotny V., Basset Y. \& Kitching R.L. 2003: Herbivore assemblages and their food resources. In Basset Y., Novotny V., Miller S.E. \& Kitching R.L.: Arthropods of Tropical Forests: A Spatio-Temporal Dynamics and Resource Use in the Canopy. Cambridge University Press, pp. 40-53.

Palacio-Varges J.G., Castaño-Meneses G. \& Gomez-Anaya J.A. 1998: Collembola from the canopy of a Mexican tropical deciduous forest. Pan-Pac. Entomol. 74: 47-54.

PERRINS C.M. 1991: Tits and their caterpillar food supply. Ibis 138: $49-54$

Southwood T.R.E. 1961: The number of species of insect associated with various trees. J. Anim. Ecol. 30: 1-8.

Southwood T.R.E. \& Henderson P.A. 2000: Ecological Methods. 3rd ed. Blackwell Science, Oxford, 575 pp.

Southwood T.R.E., Wint G.R.W., Kennedy E.J. \& Greenwood S.R. 2004: Seasonality, abundance, species richness and specificity of the phytophagous guild of insects on oak (Quercus) canopies. Eur. J. Entomol. 101: 43-50.

Stork N.E. 1987a: Guild structure of arthropods from Bornean rain forest trees. Ecol. Entomol. 12: 69-80.

STORK N.E. 1987b: Arthropod faunal similarity of Bornean rain forest trees. Ecol. Entomol. 12: 219-226.

STORK N.E. 1991: The composition of the arthropod fauna of Bornean lowland rain forest trees. J. Trop. Ecol. 7: 161-180.

Stork N.E. \& Brendell M.J.D. 1993: Arthropod abundance in lowland rainforest of Seram. In Edwards I. \& Proctor J. (eds): Natural History of Seram. Intercept Ltd, Andover, pp. 115-130.

Stork N.E., Adis J. \& Didham R.K. (eds) 1997: Canopy Arthropods. Chapman \& Hall, London, $567 \mathrm{pp}$

WEST C. 1986: Insect communities in tree canopies. In Coe M. \& Collins N.M.: Kora. Royal Geographical Society, London, pp. 209-222.

Received June 22, 2004; revised December 29, 2004; accepted January 6, 2005 